\section{The Presidentialization of Electorate's Behavior in the Election to Voivodeship Sejmiks in 2018}

\author{
Wojciech Peszyński \\ Nicolaus Copernicus University, Poland \\ https://orcid.org/0000-0002-0912-5550
}

Political Preferences 2019, vol. 24: 27-44 journals.us.edu.pl/index.php/PP Submitted: 07/08/2019 Accepted: 22/11/2019

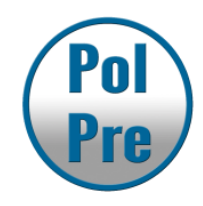

\begin{abstract}
:
The main category in this article is electoral presidentialization, understood as a tendency of voters' behavior to mirror the decisions typical for presidential elections. Here, the category under consideration is analyzed in two dimensions: leader effect and social approval for the organization of television debates of the leaders of two most important parties. The author explains the process in question on the basis of quantitative and percentage distribution of answers to two questions to be found in three editions of the nation-wide electorate study "Political Preferences". This article concerns voters' preferences in a survey that was conducted just after the self-government election in 2018. In order to grasp the specificity of electoral behavior in this particular voting, the analysis was conducted in a comparative manner, and the subject of comparison was the 2015 election to the Sejm. The results of studies organized in 2012 and 2013, when no election was organized in Poland, were also referred to in a necessary scope.
\end{abstract}

Keywords: Presidentialization, personalization of election campaign, leader effect, television debates, electorate's behavior

\title{
Introduction
}

This article constitutes the outcome of nationwide study conducted under the auspices of "Political Preferences" after the 2018 self-governmental election. This particular work is a part of a research cycle devoted to the presidentialization of electorate's behavior. In 2018, the survey included two questions identical as in previous years. The studies that took place in 2012 and 2013 were conducted in the times free from elections (Peszyński 2013, 2014). The factors that 
determined the choices of respondents in 2015, when parliamentary and presidential election took place, were completely different (Peszyński 2016) ${ }^{1}$.

The context of the election in 2018 was highly specific. First of all, it should not be looked at as a single election, despite what the term suggests. The number of elections that took place in the whole country amounted to 5306 (author's own calculation) and they concerned both legislative and executive bodies. Secondly, this particular political event opened a cycle of four elections, out of which 2019 parliamentary election seems to be the most important one. For this reason, the committees usually did not regard it as a goal itself, but rather as a strategic step to obtain a satisfactory result later. This was also reflected in the discourse of the media. The reports on the campaign focused mostly on the activity of the leaders of the main parties and the competition for the offices of mayors of the biggest and most important cities, Warsaw in particular $^{2}$.

The results of the elections to voivodeship sejmiks confirmed the thesis regarding the growth in the intensification of the most relevant sociopolitical divisions, mainly caused by geographic factors (cities versus towns and villages), but also economic and worldview ones (Markowski \& Stanley 2016; Cześnik \& Grabowska 2017).

Table 1. The results of the voting and the election to voivodeship sejmiks in 2018 in the scale of the country

\begin{tabular}{lrrr}
\hline \multicolumn{1}{c}{ Committee } & \% of votes & Mandates & \% of mandates \\
\hline Law and Justice (PiS) & 34.13 & 254 & 46.01 \\
Civic Platform, Modern, Civic Coalition (KO) & 26.97 & 194 & 35.14 \\
Polish People's Party (PSL) & 12.07 & 70 & 12.68 \\
SLD-Left Together (SLD-LR) & 6.62 & 11 & 1.99 \\
Kukiz'15 & 5.63 & 0 & 0.00 \\
Nonpartisan Local Government Activists & 5.28 & 15 & 2.71 \\
Local and regional committees (total) & 3.63 & 8 & 1.44 \\
Other parties & 5.57 & 0 & 0.00 \\
Total & 100.00 & 552 & 100.00 \\
\hline
\end{tabular}

Source: author's own calculation based on the data of PKW (2018) and Haman (2019).

\footnotetext{
${ }^{1}$ Whenever previous studies on the presidentialization of electorate's behavior are mentioned in this text, the author refers to the following articles Peszyński (2013, 2014, 2016).

${ }^{2}$ In 12 issues of "Wydarzenia" information program by Polsat, from 8-19 of October 2018, 32 pieces of news were devoted to self-governmental campaign. 18 of them concerned the choice of the city mayors $(56.2 \%), 11$ the central campaign (34.3\%), 1 the election to voivodeship sejmiks $(3.1 \%), 1$ the election of village mayors $(3,1 \%)$, and the subject of the remaining one was described as "others". 10 issues of "Rzeczpospolita" journal from 8-19 of October 2018 included 33 articles concerning the campaign under analysis. Out of them, 17 regarded the election of the city mayors $(51.5 \%), 15$ the central campaign $(45.4 \%)$ and 1 the campaign for the office of the town mayor $(3,3 \%)$ (author's own calculation).
} 
The fixation of sociopolitical divisions resulted in the limitation in the actual flow of electorate to the rural areas (between PiS and PSL). In such conditions political appeals are mostly targeted to mobilize loyal and situational voters, as the outcome of the election depends strongly on their participation, as it took place in the era of postmodern campaigns (Farrell 1996).

The aforesaid preconditions justify the studies over the subject of presidentialization of electorate's behavior. As regards the self-government election, the voting to voivodeship sejmiks seems the most credible in this aspect. In 2018, similarly as in previous regional elections, the major Polish political parties published their lists in all voivodeships and gained greater support than local committees (Table 1). Nevertheless, it is worth highlighting that despite the high level of centralization of discourse, there are certain limitations in the application of the election results into the nationwide level. In this particular election personal and program determinants of local and regional character are of greatest importance (Gędźwiłł 2017; TurskaKawa 2018). This allows to suppose that the level of presidentialization of this election would be lower than in case of parliamentary election, which is reflected in the shape of the adopted hypotheses.

\section{Methodology}

The main analytical category of this article is the presidentialization of electoral behavior. The studies concerning the phenomena and processes under consideration often mention the category of primeministerialisation. This concept is frequently used by British analysts who question the scientific value of presidentialization (Dowding 2013; Heffernan 2013). They claim that this specific term introduces "unnecessary systemic connotations". Marek Mazur (2014) prefers to refer to the process in question as "centralized personalization". Also Marina Costa Lobo and John Curtice (2015) opt to use the word "personalization" in this specific context. The functioning of the President of the United States makes the perfect example for the majority of theoretical models of presidentialization. Some researchers regard presidentialization and Americanization as synonyms (Dobek-Ostrowska 2005). However the electoral level (electoral face) provides strong arguments that support the thesis of presidentialization (Poguntke \& Webb 2013). Importantly, it is not the presidential system, but presidential election, that is the reference point here (Peszyński 2018). That heads of states are chosen indirectly is not characteristic of only presidential or semipresidential regimes. Such a manner of election exists in 


\section{Wojciech Peszyński}

a number of countries whose regime can be described as parliamentary, which can be most clearly observed in East-Central Europe (Żukiewicz 2013). Therefore the author of this article uses the terms ,primeministerialisation" and "centralized personalization" as synonymous of presidentialisation.

Presidentialization of electorate's behavior means that the behavior of electors and those elected in the parliamentary elections becomes similar to what is typical of presidential election, where the subjects elected are persons rather than political parties. The most important question, therefore, concerns the name of future Prime Minister, and not the number of seats in the parliament won by a given party. The important determinants of presidentialisation are supporting a given party because of the person of its leader and organizing television debates between the leaders of the two main parties (Poguntke \& Webb 2005; Garzia 2014).

The aim of this article is to reveal the specificity of presidentialization in electorate's behavior in the elections to voivodeship sejmiks in the context of parliamentary election. This phenomenon shall be explained by means of quantitative and percentage distribution of the answers to questions 22 and 23 asked in the nationwide survey in 2018, conducted under the auspices of "Political Preferences":

Question 22: My choice in the election to the voivodeship sejmik was motivated by the profile of the supported party rather than by its leader;

Question 23: Television debates of the leaders of the two main parties ought to become an obligatory element of any election campaign.

This survey was conducted in November and December 2018, directly after the selfgovernment election. The number of respondents, who were giving their answers by means of a Likert scale, was 964. The results shall be interpreted comparatively, most of all in the relation to a similar survey that was organized in 2015, after parliamentary election (particularly susceptible to presidentialization). When necessary, the author refers to the surveys of 2012 and 2013 as well.

The realization of the research goal adopted in this study requires the verification of two hypotheses:

Hypothesis 1: The person of a party leader determined electorate's decision less in the elections to voivodeship sejmiks in 2018 than in the election to Sejm in 2015. 
Hypothesis 2: The citizens show less interest in the organization of television debates between the leaders of the two major political parties after the elections to voivodeship sejmiks in 2018 than directly after the election to Sejm in 2015.

The tools that were used to measure the level of the "leader effect" are percentage and quantity indication of "probably not" and "definitely not" options. In the verification of the first hypothesis, the respondents who did not participate in the election were ignored, as it would be absurd to investigate their decisions in this aspect. Also the voters supporting local and regional committees, as they lack nationwide leaders. The similar case regarded the Nonpartisan Local Government Activists, an organization that did not participate in the parliamentary election ${ }^{3}$. As regards ,other parties”, it is difficult to speak about the "leader effect”, when several parties are under consideration, which is why it was excluded from the analysis. Therefore, in the measurement of the "leader effect" indicator, five committees, which participated in both 2018 elections to voivodeship sejmiks and the 2015 parliamentary elections, were taken into account. They include PiS, KO (in 2015 under the name PO) ${ }^{4}$, PSL, SLD-LR i Kukiz'15. In the last self-government election these subjects achieved the support of $85.42 \%$ in the scale of the country (Table 1).

Provided that the value of this indicator for the five committees and the majority of the units under analysis is higher in case of the 2015 election to the Sejm, the hypothesis will be confirmed. If the total value and the value for vast majority of the units (at least four) is lower, it will be confirmed only partially. The same result will be achieved if the total value of the indicator for the five committees is lower and at the same time higher in the vast majority of units. In the situation when the indicator value for the committees is lower and simultaneously it is higher for the majority of units, the hypothesis shall be refuted.

The indicator, on the basis of which the necessity to organize television debates shall be verified, includes percentage and quantity indications of "probably yes" and "definitely yes". The measurement of this indicator takes place on three levels: general, five committees (as in

\footnotetext{
${ }^{3}$ It is worth highlighting that the respondents claimed their support for Nonpartisan Local Government Activists in the constituencies in which this committee did not register their lists. For instance, in the Kuyavian-Pomeranian region, where the "Political Preferences" studies were coordinated by the author of this article, Nonpartisan Local Government Activists registered their list in one out of six constituencies, and still the respondents from the remaining five declared their support for this organization.

${ }^{4}$ For the Civic Coalition the subject of comparison in the election to the Sejm in 2015 was most of all PO and .N only in a necessary scope. Despite the coalition character of this political subject, after three years after the abovementioned election, due to certain factors (mainly the loss of budget subsidies), .N became organizationally and financially dependent on PO.
} 


\section{Wojciech Peszyński}

case of the "leader effect") and for the two main political parties (depending on the result of the voting). Supposing that the value of this indicator is higher in all the three cases for the 2015 election, the hypothesis will be confirmed. If it is lower on all the levels, the hypothesis will be refuted. If it is higher in at least one case, it will be confirmed partially.

\section{Leader effect}

"Leader effect", usually specified as a percentage value, is the degree to which election leaders influence the voting result of their party (Mughan 2005; Holmberg \& Oscarsson 2011; Garzia 2014; Daoust et al. 2019). The category "election leader" is wider than "party leader". Not only does it refer to the head of a party, but also to other politicians whose role in the committee was crucial and who impersonate the image of their organization. This notion is perfectly reflected inby the term spitzenkandidate (Brettschneider 2002; Schulze 2016).

As far as the image creation is concerned, in the 2018 campaign of PiS this notion can be applied to both Jarosław Kaczyński and Mateusz Morawiecki. The role of the PM was to complete the image of the party with political and personal features that Kaczyński lacks, so that the offer of this committee was more attractive for the voters in bigger cities. The personal strategy of KO was focused on conciliation capabilities, understood as the abilities of people of different gender and ideological orientations to cooperate. Such values were to be introduced by Schetyna (the leader of PO), Katarzyna Lubnauer (the leader of .N) and Barbara Nowacka (initiator of the Polish Initiative association). However, out of the three politicians mentioned above, Schetyna, as a leader of the organization that carried the financial and organizational responsibility for the campaign, best matches the description of an "election leader".

Out of the remaining subjects, the highest level of institutionalization was visible in PSL and SLD. These parties, during several decades of their functioning, were able to organizationally endure a number of leaders. As regards the campaign under analysis, they were lead by Władysław Kosiniak-Kamysz and Włodzimierz Czarzasty respectively. The highest level of personalization was present in Kukiz'15, as the name of the party includes the name of its leader.

The study conducted by CBOS (2018) shows that during the last days of the campaign the level of social familiarity with the previously mentioned politicians was varied. While the leaders of PiS, KO or Kukiz'15 were commonly recognized, respondents had doubts with 
regard to PSL and SLD. The results of this study shows that Kosiniak-Kamysz was not identified by $36 \%$ and Czarzasty by $42 \%$ of the voters questioned, which could affect their preferences.

The indicators that were used to measure the "leader effect" are percentage and quantity indications of the options "probably not" and "definitely not" in question number 22 . The choice of "probably yes" and "definitely yes" options means that the respondents, while making their decisions are motivated by the affiliation to a given party (doctrine rooting, program, candidate or other local and regional determinants).

Table 2. Quantity and percentage distribution of answers to the question: "My choice in the election to the Voivodeship Sejmik was motivated by the profile of the supported party rather than by its leader" in particular electorates in the election to voivodeship sejmiks in 2018

\begin{tabular}{|c|c|c|c|c|c|c|}
\hline $\begin{array}{c}\text { In the election to } \\
\text { voivodeship sejmiks in } 2018 \\
\text { I voted: }\end{array}$ & $\begin{array}{c}\text { Definitely } \\
\text { no }\end{array}$ & $\begin{array}{l}\text { Probably } \\
\text { no }\end{array}$ & $\begin{array}{c}\text { Hard to } \\
\text { tell }\end{array}$ & $\begin{array}{l}\text { Probably } \\
\text { yes }\end{array}$ & $\begin{array}{l}\text { Definitely } \\
\text { yes }\end{array}$ & Total \\
\hline No answer & $\begin{array}{r}0 \\
0.00 \%\end{array}$ & $\begin{array}{r}0 \\
0.00 \%\end{array}$ & $\begin{array}{r}1 \\
100.00 \%\end{array}$ & $\begin{array}{r}0 \\
0.00 \%\end{array}$ & $\begin{array}{r}0 \\
0.00 \%\end{array}$ & $\begin{array}{r}1 \\
100.00 \%\end{array}$ \\
\hline $\begin{array}{l}\text { Nonpartisan local } \\
\text { government activists }\end{array}$ & $\begin{array}{r}6 \\
12.00 \%\end{array}$ & $\begin{array}{r}13 \\
26.00 \%\end{array}$ & $\begin{array}{r}12 \\
24.00 \%\end{array}$ & $\begin{array}{r}13 \\
26.00 \%\end{array}$ & $\begin{array}{r}6 \\
12.00 \%\end{array}$ & $\begin{array}{r}50 \\
100.00 \%\end{array}$ \\
\hline Polish People's Party & $\begin{array}{r}3 \\
4.62 \%\end{array}$ & $\begin{array}{r}14 \\
21.54 \%\end{array}$ & $\begin{array}{r}9 \\
13.85 \%\end{array}$ & $\begin{array}{r}27 \\
41.54 \%\end{array}$ & $\begin{array}{r}12 \\
18.46 \%\end{array}$ & $\begin{array}{r}65 \\
100.00 \%\end{array}$ \\
\hline $\begin{array}{l}\text { Civic Platform. Modern. } \\
\text { Civic Coalition }\end{array}$ & $\begin{array}{r}11 \\
4.78 \%\end{array}$ & $\begin{array}{r}35 \\
15.22 \%\end{array}$ & $\begin{array}{r}46 \\
20.00 \%\end{array}$ & $\begin{array}{r}98 \\
42.61 \%\end{array}$ & $\begin{array}{r}40 \\
17.39 \%\end{array}$ & $\begin{array}{r}230 \\
100.00 \%\end{array}$ \\
\hline SLD Left Together & $\begin{array}{r}1 \\
2.44 \%\end{array}$ & $\begin{array}{r}4 \\
9.76 \%\end{array}$ & $\begin{array}{r}6 \\
14.63 \%\end{array}$ & $\begin{array}{r}19 \\
46.34 \%\end{array}$ & $\begin{array}{r}11 \\
26.83 \%\end{array}$ & $\begin{array}{r}41 \\
100.00 \%\end{array}$ \\
\hline Kukiz'15 & $\begin{array}{r}2 \\
6.06 \%\end{array}$ & $\begin{array}{r}2 \\
6.06 \%\end{array}$ & $\begin{array}{r}10 \\
30.30 \%\end{array}$ & $\begin{array}{r}14 \\
42.42 \%\end{array}$ & $\begin{array}{r}5 \\
15.15 \%\end{array}$ & $\begin{array}{r}33 \\
100.00 \%\end{array}$ \\
\hline Law and Order & $\begin{array}{r}18 \\
8.00 \%\end{array}$ & $\begin{array}{r}45 \\
20.00 \%\end{array}$ & $\begin{array}{r}48 \\
21.33 \%\end{array}$ & $\begin{array}{r}83 \\
36.89 \%\end{array}$ & $\begin{array}{r}31 \\
13.78 \%\end{array}$ & $\begin{array}{r}225 \\
100.00 \%\end{array}$ \\
\hline Local/Regional Committee & $\begin{array}{r}5 \\
10.00 \%\end{array}$ & $\begin{array}{r}7 \\
14.00 \%\end{array}$ & $\begin{array}{r}8 \\
16.00 \%\end{array}$ & $\begin{array}{r}27 \\
54.00 \%\end{array}$ & $\begin{array}{r}3 \\
6.00 \%\end{array}$ & $\begin{array}{r}50 \\
100.00 \%\end{array}$ \\
\hline Other & $\begin{array}{r}10 \\
15.38 \%\end{array}$ & $\begin{array}{r}5 \\
7.68 \%\end{array}$ & $\begin{array}{r}16 \\
24.62 \%\end{array}$ & $\begin{array}{r}23 \\
35.38 \%\end{array}$ & $\begin{array}{r}11 \\
16.92 \%\end{array}$ & $\begin{array}{r}65 \\
100.00 \%\end{array}$ \\
\hline Did not vote & $\begin{array}{r}14 \\
9.79 \%\end{array}$ & $\begin{array}{r}38 \\
26.57 \%\end{array}$ & $\begin{array}{r}55 \\
38.46 \%\end{array}$ & $\begin{array}{r}23 \\
16.08 \%\end{array}$ & $\begin{array}{r}13 \\
9.09 \%\end{array}$ & $\begin{array}{r}143 \\
100.00 \%\end{array}$ \\
\hline Do not remember & $\begin{array}{r}8 \\
13.11 \%\end{array}$ & $\begin{array}{r}9 \\
14.75 \%\end{array}$ & $\begin{array}{r}23 \\
37.70 \%\end{array}$ & $\begin{array}{r}17 \\
27.87 \%\end{array}$ & $\begin{array}{r}4 \\
6.56 \%\end{array}$ & $\begin{array}{r}61 \\
100.00 \%\end{array}$ \\
\hline Total & $\begin{array}{r}78 \\
8.09 \%\end{array}$ & $\begin{array}{r}172 \\
17.84 \%\end{array}$ & $\begin{array}{r}234 \\
24.27 \%\end{array}$ & $\begin{array}{r}344 \\
35.68 \%\end{array}$ & $\begin{array}{r}136 \\
14.11 \%\end{array}$ & $\begin{array}{r}964 \\
100.00 \%\end{array}$ \\
\hline
\end{tabular}

Source: own elaboration. 


\section{Wojciech Peszyński}

Similarly as in previous elections, almost every forth respondent chose the "hard to tell" answer (24.27\% - 234 answers). It can be assumed that many respondents may perceive such question as unintelligible or are unable to specify the motivation for their electoral decisions. The choice of such an option can also be interpreted as a tactical or negative voting. In such a situation, however, it is impossible to state whether it was the person of a leader or other factors that determined their choice to support a particular committee in the elections to voivodeship sejmiks.

The respondents most frequently identified the determinants of their decisions with the profile of the party (49.79\% - 480 answers), which meant a $4.51 \%$ drop (22 answers) when compared to the result in 2015. The indicator of the "leader effect" generally raised to $25.93 \%$ (250 answers) in the same period. These results, however, ought to be approached carefully due to answers of those who declared absence in the election $(14.83 \%$ - 143 respondents). Out of this group, 16 more respondents $(9.19 \%)$ claimed that their decision in the elections to voivodeship sejmiks was motivated by the person of a leader rather than the profile of the party. Indication of their preferences by the non-voting respondents seems irrational and distorts the final result of the study.

Among the committees under consideration, the highest level of "leader effect" was observed in PiS (28\%). During the campaign to the Sejm in 2015, the role of a "primeministerial candidate" was given to Beata Szydło. However, the three-year period of the party’s being in power dispelled any doubts concerning the identity of its decisive body. Jarosław Kaczyński, can be described as an director, not actor, of this "political spectacle" (Matyja 2018), ready to give up the privileges connected with the status of the president or Prime Minister in order to fulfill his own political goals. Such an attitude resulted most of all from certain deficiencies of his image. The person who could boast a greatest level of public trust was Prime Minister Morawiecki ${ }^{5}$, who for that reason became strongly involved in the promotion of the party and managed to prove his communication skills. These factors could contribute to the increase in the level of "leader effect" rate by $9.5 \%$ (24 persons) in comparison to 2015. In 2018, $8.13 \%$ less of the PiS electorate chose the options "definitely yes" and "probably yes", when compared to the study that had been conducted three years earlier. However, still more than a half

\footnotetext{
${ }^{5}$ According to the study by CBOS (2018) conducted right before the self-government election in 2018 , $41 \%$ of respondents declared trust and $44 \%$ of the mistrust to Jarosław Kaczyński. In case of Mateusz Morawiecki, these values amounted to $54 \%$ and $28 \%$ respectively.
} 
of the respondents declaring their support for the party (50.67\% - 114 answers) identify their choice with its profile, which is reflected in the impact of the "leader effect" on the final result of PiS.

As regards Civic Coalition, the level of "leader effect" is lower. It amounted to $20 \%$ (46 answers). The reasons for such a situation might be twofold. Firstly, Grzegorz Schetyna could not boast a high level of social confidence. Secondly, KO became the greatest beneficiary of the tactic voting of those unwilling to support PiS. Schetyna, despite his success within the party, did not manage to win social trust, which was proven in the study by CBOS $(2018)^{6}$. This contributed to the level of "leader effect" of KO, which in 2018 amounted to $20 \%$ and decreased by $4.7 \%$ in comparison to 2015, when Ewa Kopacz was the "election leader". However, it needs to be mentioned that in all the studies devoted to presidentialization of electoral behavior conducted under the auspices of "Political Preferences" the leaders of PO did not show a low level of the factor under consideration. It is clearly visible in the analysis deriving from the period when Donald Tusk, the former Prime Minister, was an unquestionable leader of the party (20.7\% in 2012 and $18.7 \%$ in 2013).

It is legitimate to claim that in $2018 \mathrm{KO}$ candidates profited most from the tactic voting of those who feared the victory of PiS. KO and PO kept occupying the second position in the opinion polls. The strategic mistakes made by PiS in the final week of the campaign mobilized this group to participate in the elections (Stankiewicz 2018; Szacki 2018). On the level of sejmiks this mobilization was visible in the highest attendance in the history if these elections (54.9\%), which could be observed in big cities in particular (PKW 2018).

The "Leader effect" amounted to $26.15 \%$ (17 answers) for PSL, which for this party is the highest result ever. In comparison to the situation in 2015 , the value increased by $6.75 \%$. On the other hand, provided that the leader of the party was not Kosiniak-Kamysz, public support could be similar. PSL achieves better results in the elections to sejmiks than in parliamentary ones, which may be due to the rooting of the party in strong local and regional structures, and propitious decisions of the voters, who participate mostly in self-government elections (Sutowski 2019). The proof for this thesis consists in the number of responses indicating the leader as the motivation for voting decisions (60\% - 39 answers).

\footnotetext{
${ }^{6}$ In the study by CBOS (2018) concerning the social trust in politicians, conducted right before the self-government election in 2018, 23\% of respondents declared trust and 47\% mistrust for Grzegorz Schetyna.
} 


\section{Wojciech Peszyński}

Due to the high level of institutionalization, especially as regards Polish conditions, SLD leader has a limited impact on the result of the party. This can be observed on the basis of all the four studies under consideration. When compared to other political subjects, the level of "leader effect" in SLD (and in Left United in 2015), was low. During the period under analysis the role of "election leader" was performed by three politicians: L. Miller ( 2012 and 2013), B. Nowacka (2015) and W. Czarzasty (2018). The "leader effect" value amounted to $12.2 \%$ (6 respondents) and $12 \%$ in 2018 and 2015 respectively. In 2018, 73.17\% of the respondents voting for SLD (30 answers) explained their decision with factors connected with the "party profile" - almost 6\% more than in the study conducted in 2015.

It is surprising that the party whose name includes the surname of its leader, Kukiz'15, achieved the lowest rate from all the analyzed committees (12.12\%, 4 answers). In 2015, this value was more than twice as big (25.6\% - 23 answers). It ought to be remembered, however, that at this time the survey was organized in the year of double elections, just after the one to the Sejm. Kukiz'15 achieved the support of $8.82 \%$ and managed to introduce 42 members into the Sejm, and in the majority of cases it was due to the popularity of its leader. In 2018 the situation of the party was considerably worse, which resulted in the lack of mandates to voivodeship sejmiks (Table 1). The party introduced their lists in all the constituencies, which stands for good organization and high level of mobilization in seemingly weak structures. This may be the reason for the fact that $57.57 \%$ (19 answers) of the party supporters associate their choice with the party profile, and $30.3 \%$ (10) chose the "Hard to tell" answer.

\section{Television debates of the leaders of two major parties}

In Poland, the term "television debate" relates to the discussion between two or more parties. However, in several countries of Western Europe it is not so obvious. In Germany, for instance, this notion refers to the meeting of the leaders of all the national committees, and the dispute of the spitzenkandidaten of two main parties is known as "television duel" (fernsehnduell, TV Duell) (Anstead 2015). Due to the fact that English language does not include such restrictions, the author shall use these terms interchangeably.

Regardless of terminological issues, it is worth highlighting that television debates are not limited to the final stage of rivalry for the office of the president. Despite the growing role of the social media in political communication (Barlett 2018), the debates of the leaders of two major 
parties still constitute the important ritual in the parliamentary campaigns (Seklecka 2017). This can be exemplified with by the course of election strife in 2017 , when such events were organized in the Netherlands (M. Rutte - G. Wilders) or Germany (A. Merkel - M. Schulz).

In Poland, television debates are strongly associated with the final stage of presidential election, which can be proved by the fact that they usually take place between the first and the second ballot. Duels between the Prime Minister and the "election leader" of the biggest opposition party are still rare. So far, such events were organized in 2007 and 2015. Although the discussion between Kaczyński and Tusk was essential for the result of the election, the debate between Kopacz and Szydło in 2015 was not so crucial (Mazur \& Konieczny 2012; BudzyńskaDaca 2015; Kochan 2016; Peszyński 2016a).

Art. 120 of the Election Code (2011) demands public television to conduct debates between the representatives of national committees before the elections to the Parliament, European Parliament and between the candidates for the office of the president. Before selfgovernment elections debates are not obligatory.

Nevertheless, a week before the end of the first part of self-government campaign in 2018 a television debate of those running for the office of the Mayor of Warsaw took place. All 14 candidates took party in the event and it is worth our attention for two reasons. Firstly, the debate was broadcast nationally by the three main television stations. According to telemetry data, it was viewed by 3.1 million people, which is more than the number of potential voters in the capital (PKW 2018). Secondly, it can be expected that a large number of viewers treated it as a rivalry between two dominant candidates, that is Trzaskowski (KO) and Jaki (PiS) (Stankiewicz 2018; Szacki 2018).

Strong centralization of discourse in 2018 made it relevant to ask respondents the question concerning their opinion on the organization of debates during self-government elections. This was measured on three levels, general, two leading parties, and five parties that achieved the best result during the elections, on the basis of the number and percentage of answers "probably yes" and "definitely yes" to question number 23. 


\section{Wojciech Peszyński}

Table 3. Quantity and percentage distribution of answers to question „Television debates of the leaders of two main parties should became an obligatory element of any election campaign" in particular electorates in the electionto the voivodeship sejmiks in 2018

\begin{tabular}{crrrrrr}
\hline $\begin{array}{c}\text { In the 2018 election to the } \\
\text { voivodeship sejmiks I voted }\end{array}$ & $\begin{array}{c}\text { Definitely } \\
\text { no }\end{array}$ & $\begin{array}{c}\text { Probably } \\
\text { no }\end{array}$ & $\begin{array}{c}\text { Hard to } \\
\text { tell }\end{array}$ & $\begin{array}{c}\text { Probably } \\
\text { yes }\end{array}$ & $\begin{array}{c}\text { Definitely } \\
\text { yes }\end{array}$ & Total \\
\hline No answer & $0.00 \%$ & $0.00 \%$ & $0.00 \%$ & $0.00 \%$ & $100.00 \%$ & $100.00 \%$ \\
Nonpartisan Local & 2 & 5 & 14 & 12 & 17 & 50 \\
Government Activists & $4.00 \%$ & $10.00 \%$ & $28.00 \%$ & $24.00 \%$ & $34.00 \%$ & $100.00 \%$ \\
Polish People's Party & 3 & 5 & 19 & 20 & 18 & 65 \\
Civic Platform, Modern, Civic & $4.62 \%$ & $7.69 \%$ & $29.23 \%$ & $30.77 \%$ & $27.69 \%$ & $100.00 \%$ \\
Coalition & 6 & 18 & 45 & 94 & 67 & 230 \\
SLD Left Together & $2.61 \%$ & $7.83 \%$ & $19.57 \%$ & $40.87 \%$ & $29.13 \%$ & $100.00 \%$ \\
Kukiz'15 & 5 & 3 & 12 & 13 & 8 & 41 \\
& $12.20 \%$ & $7.32 \%$ & $29.27 \%$ & $31.71 \%$ & $19.51 \%$ & $100.00 \%$ \\
Law and Justice & 1 & 3 & 9 & 9 & 12 & 34 \\
& $2.94 \%$ & $8.82 \%$ & $26.47 \%$ & $26.47 \%$ & $35.29 \%$ & $100.00 \%$ \\
Local/regional committee & 6 & 25 & 46 & 77 & 68 & 222 \\
& $2.70 \%$ & $11.26 \%$ & $20.72 \%$ & $34.68 \%$ & $30.63 \%$ & $100.00 \%$ \\
Other & 6 & 7 & 8 & 17 & 12 & 50 \\
& $12.00 \%$ & $14.00 \%$ & $16.00 \%$ & $34.00 \%$ & $24.00 \%$ & $100.00 \%$ \\
Did not vote & 10 & 9 & 14 & 21 & 11 & 65 \\
& $15.38 \%$ & $13.85 \%$ & $21.54 \%$ & $32.31 \%$ & $16.92 \%$ & $100.00 \%$ \\
Do not remember & 15 & 20 & 28 & 44 & 38 & 145 \\
& $10.34 \%$ & $13.79 \%$ & $19.31 \%$ & $30.34 \%$ & $26.21 \%$ & $100.00 \%$ \\
& 3 & 7 & 19 & 19 & 13 & 61 \\
& $4.92 \%$ & $11.48 \%$ & $31.15 \%$ & $31.15 \%$ & $21.31 \%$ & $100.00 \%$ \\
& 57 & 102 & 214 & 326 & 265 & 964 \\
& $5.91 \%$ & $10.58 \%$ & $22.20 \%$ & $33.82 \%$ & $27.49 \%$ & $100.00 \%$ \\
\hline
\end{tabular}

Source: own elaboration.

In 2018 such answers were given by 591 respondents (61.31\%). This proportion is comparable to the results of the study conducted in 2015 (61.87\%, 537 answers), when three duels were organized between the candidates of the two largest parties (two in presidential and one in the parliamentary campaign) and debate between the eight election committees leaders particularly important for the result of the voting to the Sejm (Peszyński 2016a). It is worth noticing that in comparison to the situation of the double campaign in 2015 , in the analysis under consideration, there was a $3.31 \%$ decrease in the number of opponents of such a form of discussion.

All the studies conducted so far showed that the largest number of debates followers can be found among those voting for PO (KO). In the years 2011-2015 the key candidates of this 
political body participated in 7 out of 8 of such events and in the majority of cases performed better than their opponents. PO seems to be a typical catch all party, an organization that is relatively program-flexible and that finds itself well in the era of television-dominated politics (Karnowski \& Mistewicz 2010). In 2018, 70\% (161 answers) of the respondents favoring KO supported the idea of obligatory television debates. During the campaign, such a debate would provide an opportunity to level the chances in the rivalry against PiS on the national level. On the other hand, the leader of PO, Grzegorz Schetyna, lacks communication skills possessed by Kaczyński or Morawiecki. Still, such an idea did not appear in the agenda of the campaign.

In all the four studies, the number of the supporters of debates among the electorate of PiS was similar. This rate was the highest in 2015 and amounted to $68.9 \%$ (137 answers). Three years later it decreased to $65.3 \%$ (145 answers) and was identical to that in 2012, a year without any election. However, the fact that the percentage of the debates followers is growing steadily does not pose any essential argument in the aspect of the rivalry against PO. Before parliamentary elections the duels were organized when it was profitable for the strategy of PiS. It is expected that in the elections to come this factor will be crucial for the organization of such events.

For all the studies, the percentage of those supporting the institutionalization of debates was higher among the electorates of the two major parties than on a general level. This proves that the significance of the party determines the opinion of its followers. In 2018, it amounted to $67.69 \%$ (306 out of 452 respondents) and was lower than three years earlier $-70.86 \%$ (287 out of 405 respondents). It is worth remembering, however, that in the period of the double campaign in 2015, four debates, including three bilateral ones, were organized. Still, it ought to be noticed that not always the organization of such events has impact on the number of their supporters. The highest rate of this indicator, for both PO and PiS, was observed in 2012 (72.63\% - 345 out of 475 respondents). Importantly, this form of political communication was supported by the supporters of PO and SLD, not PiS.

In comparison to the results of the study conducted in 2015 , there was a $8.46 \%$ growth among the followers of Kukiz'15. However, the analysis of data requires certain carefulness in case of this particular party. In 2018, slightly over 30 respondents declared their support for the party, which constitutes merely one third of the result in the parliamentary election in 2015.

The conclusions seem more credible in case of PSL, as the party was supported by 65 respondents (44 in 2015). In this case the percentage of those who opt for debates increased 


\section{Wojciech Peszyński}

by $5.16 \%$ (15 persons), which makes the highest result in all the studies. During parliamentary campaign in 2015, the debate between the leaders of the eight most important parties was attended by Piechociński, who made a good impression when compared to his opponents (Leśniczak 2018). Nevertheless, the former leader of PSL was less trusted by the supporters of the party than Kosiniak-Kamysz during self-governmental campaign ${ }^{7}$. For this reason, it is legitimate to associate this growth with the change in the leadership of the party. On the other hand, in the current conditions on Polish political stage, the leader of PSL could have no chance to participate in such a debate. Moreover, it ought to be mentioned that the respondents supporting PSL relatively often gave the "hard to tell" answer (29.23\%).

Among the electors of SLD-LR in 2018 the proportion of the followers of obligatory debates amounted to $51.22 \%$, which was the lowest result for this organization in the history of the studies. It is worth remembering that at the times when the party was lead by Leszek Miller the values of this indicator were $73.1 \%$ and $66.7 \%$ in 2012 and 2013 respectively. In 2015, when the leader of Left Together was Barbara Nowacka, there was a decrease to $55.3 \%$ in this aspect. Importantly, her performance during the debate was assessed as average, especially when compared to Adrian Zandberg, the leader of a left-wing party Together (Peszyński 2016a).

When compared to other leaders of SLD, the leadership of Włodzimierz Czarzasty seems not so expressive, which is confirmed by social unfamiliarity with his person by two out of five respondents (CBOS 2018). Still, due to the decreasing tendency of the party, lasting for several years, the candidate of this organization had small chances to enter the debate. Moreover, it does not seem that SLD is going to rebuild its position from the turn of the $20^{\text {th }}$ and $21^{\text {st }}$ centuries. Its electorate is therefore aware that any debate to be organized would host the representatives of PiS and PO, which would cause protests of SLD and other parties, as it happened before the duel between Ewa Kopacz and Beata Szydło in 2015 (Peszyński 2016a).

Proportionally more respondents opting for television debates were found among the electorate of Nonpartisan Local Government Activists (58\%, 29 answers), regional committees $(58 \%, 29$ answers), or even those who did not vote in this election $(56.5 \%, 82$ answers). In all these sectors, the necessity to organize discussion of the leaders of two most important parties is acknowledged by more than half of the people questioned. Still, the values of this factor for Nonpartisan Local Government Activists, local committees and non-voters were

\footnotetext{
${ }^{7}$ In the final days of the campaign in 2015, Piechociński could boast the trust of $24 \%$ and distrust of $22 \%$ of the respondents (CBOS 2015). The day before self-government election in 2018, this values amounted for $28 \%$ and $18 \%$ respectively (CBOS 2018).
} 
proportionally lower than for the five main parties $(65.2 \%)$, which clearly shows that the status of the committee in self-government election has an impact on the attitude of its electorate towards the institutionalization of debates.

\section{Conclusions}

As it was mentioned in the part devoted to methodology, the aim of this article if to verify two analytical hypotheses:

Hypothesis 1: The person of a party leader determined electorate's decision less in the elections to voivodeship sejmiks in 2018 than in the election to the Sejm in 2015.

Hypothesis 2: The citizens show less interest in the organization of television debates between the leaders of the two major political parties after the elections to voivodeship sejmiks in 2018 than directly after the election to the Sejm in 2015.

The first hypothesis was refuted due to two factors. First of all, in case of three out of five political subjects, the person of a leader determined the electorate's decisions in 2018 than in 2015. As regards KO (PO in the 2015 election), and Kukiz'15 the value of this indicator was lower than three years earlier and amounted to $4.7 \%$ and $13.48 \%$ respectively. Among the respondents declaring their support for PiS and PSL, the indicator under analysis reached a distinctively higher level $-8.4 \%$ and $5.76 \%$ respectively. In case of SLD (ZL in 2015), a progress of $0.2 \%$ was observed.

Table 4. "Leader effect" in the elections to voivodeship sejmiks in 2018 against the election to the Sejm in 2015

\begin{tabular}{lrrrrrr}
\hline \multirow{2}{*}{ Committee } & \multicolumn{3}{c}{ Election to sejmiks in 2018 } & \multicolumn{3}{c}{ Election to Sejm RP 2015 } \\
& Leader & Committee & \multicolumn{1}{c}{$\%$} & Leader & Committee & \% \\
\hline PiS & 63 & 225 & 28.00 & 39 & 199 & 19.60 \\
KO/PO & 46 & 230 & 20.00 & 51 & 206 & 24.70 \\
PSL & 17 & 65 & 26.16 & 9 & 44 & 20.40 \\
SLD-LR/ZL & 5 & 41 & 12.20 & 8 & 67 & 12.00 \\
Kukiz'15 & 4 & 33 & 12.12 & 23 & 90 & 25.60 \\
5 Committees together & 135 & 594 & 22.72 & 130 & 606 & 21.45 \\
\hline
\end{tabular}

As "leader" one should understand the sum of answers "definitely not" and "probably not" to question number 22 Source: author's own calculation based on nation-wide study of electorate "Political Preferences" in 2015 and 2018.

Secondly, the total "leader effect" value for five committees in the elections to voivodeship sejmiks amounted to $22.72 \%$ (135 out of 594 voters) and was $1.72 \%$ higher than the value reached in the election to the Sejm in 2015. Out of the people voting for the five major 


\section{Wojciech Peszyński}

parties in 2018, 57.23\% (340 respondents) associated their decision with the "profile of the party", which in comparison to the data from 2015 means $0.96 \%$ progress. This leads to the conclusion that in the aspect of presidentialization, the voting to voivodeship sejmiks in 2018 resembled more the specificity of the parliamentary election than that of regional elections, theoretically far more correlated to the issues of particular regions.

The second hypothesis was partially confirmed due to two arguments. Firstly, on the general level there are proportionally less followers of the institutionalization of television debates during the elections to voivodeship sejmiks. Secondly, when compared to 2015, the year of double election, in 2018 the support for such duels among the electorate of two main parties (whose leaders would participate in the event - WP) decreased, and this decrease amounted to $3.17 \%$. On the other hand, there are factors that speak for the refutation of this hypothesis. For five key committees the value is higher for the 2018 election, even if the difference is only $2 \%$. It is worth noticing that taking into consideration the quantitative aspect of this comparison, the results are opposite to percentage values in every case, which is due to the bigger research sample in 2018 and bigger quantitative support for five committees in 2015.

Table 5. The level of indicator of obligatory debates between leaders of two main parties

\begin{tabular}{lrrrrrr}
\hline \multirow{2}{*}{ Committee } & \multicolumn{3}{c}{ Election to sejmiks in 2018 } & \multicolumn{3}{c}{ Election to Sejm RP 2015 } \\
& Followers & Committee & \% & Followers & Committee & \% \\
\hline PiS & 145 & 222 & 65.31 & 137 & 199 & 68.90 \\
KO/PO & 161 & 230 & 70.00 & 150 & 206 & 72.80 \\
PSL & 38 & 65 & 58.46 & 23 & 44 & 52.30 \\
SLD-LR/ZL & 21 & 41 & 51.22 & 37 & 67 & 55.30 \\
Kukiz'15 & 21 & 34 & 61.76 & 48 & 90 & 53.30 \\
5 committees together & 386 & 592 & 65.20 & 395 & 606 & 65.18 \\
2 main parties & 306 & 452 & 67.69 & 287 & 405 & 70.86 \\
Total outcome & 591 & 964 & 61.31 & 573 & 926 & 61.87 \\
\hline
\end{tabular}

*Followers of obligatory debates

Source: author's own calculation based on nation-wide study of electorate "Political Preferences" in 2015 and 2018.

The debates of "election leaders" constitute an element of modern architecture of political communication, increasingly dominated by the style of the social media. This means that such events provide the voters with convenient opportunity to express their thoughts and feelings on Facebook, Twitter or YouTube (Gdula 2018). For this reason, social demand for medial events of this kind is not decreasing proportionally to the role of television in political communication, which was partially confirmed by the results of this study. 
To summarize, the level of presidentialization of electoral behavior in the elections to voivodeship sejmiks in 2018 was characteristic rather for parliamentary than regional election. In this specific case, it is legitimate to search for the reasons for such a situation in the fact that the election under analysis was not only an election itself, and as it opened a cycle of four elections, it should be regarded as a stage in a long-distance competition between parties whose final point was the election to the Sejm in 2019. Moreover, to this result contributed the growing polarization of the spectrum of rivalry between PiS and the opposition parties (KO, PSL, SLDLPR). Such features are also present in the discourse of the campaign, which was visible mostly in its centralization.

\section{References:}

Anstead, N., (2015), Television Debate in Parliamentary Democracies. LSE Media Policy Brief, 13. London: London School of Economics and Political Science. http://www.1se.ac.uk/media@1se/documents/MPP/LSE-MPPPolicy-Brief-13-Televised-Election-Debates-in-the-UK.pdf (4/07/2019).

Barlett, J. (2018). Ludzie przeciw technologii. Jak Internet zabija demokrację. Katowice: Wyd. Sonia Draga.

Brettschneider, F. (2002). Spitzenkandidaten und Wahlerfolg. Personalizierung - Kompetenz - Partaien. Ein internationaler Vergleich. Wiesbaden: Westdeutcher Verlag.

Budzyńska-Daca, A. (2015). Retoryka debaty. Polskie wielkie debaty przedwyborcze 1995-2010. Warszawa: PWN.

CBOS (2015). Zaufanie do polityków w ostatnich dniach kampanii wyborczej. Komunikat z badań CBOS nr 146/2015. Warszawa: Centrum Badania Opinii Społecznej.

CBOS (2018). Zaufanie do polityków przed wyborami samorządowymi. Komunikat z badań CBOS nr 141/2018. Warszawa: Centrum Badania Opinii Społecznej.

Costa Lobo, M., \& Curtice, J. (2015). Personality Politics? The Role of Leader Evaluations in Democratic Elections, Oxford: Oxford University Press.

Cześnik, M., \& Grabowska, M. (2017). Popękane polskie społeczeństwo jako pole badawcze - dane, fakty, mity. Przegląd Socjologiczny, LXVI(3), 9-43.

Daoust, J-F., Blais, A., Peloquin-Skulski, G. (2019). What do voters do when they prefer a leader another party. Party Politics. https://doi.org/10.1177/1354068819845100.

Dobek-Ostrowska, B. (2005). Profesjonalizacja kampanii wyborczych we współczesnym świecie i jej konsekwencje. In: B. Dobek-Ostrowska (eds.). Kampania wyborcza: marketingowe aspekty komunikowania politycznego (pp. 1133). Wrocław: Wyd. Uniwersytetu Wrocławskiego.

Dowding, K. (2013). The Prime Ministerialisation of the British Prime Minister. Parliamentary Affairs, 66(3), 61735 .

Dudek, A. (2016). Historia polityczna Polski 1989-2015. Kraków: Znak.

Farrell, D. (1996). Campaign Strategies and Tactics. In: R. LeDuc, R. Niemi, \& P. Norris (eds.), Comparing Democracies. Elections and Voting in Global Perpectives (pp. 158-81). Thousand Oaks, CA: Sage.

Garzia, D. (2014). Personalization of Politics and Electoral Change. London: Palgrave.

Gędźwiłł, A. (2017). Różne wybory, różne elektoraty? Specyfika uczestnictwa w wyborach lokalnych. Studia socjologiczne, 1 (224), 81-102.

Gdula, M. (2018). Nowy autorytaryzm. Warszawa: Wyd. Krytyki Politycznej. 


\section{Wojciech Peszyński}

Haman, J. (2019). Wybory samorzadowe 2018. Raport z obserwacji. Warszawa: Fundacja Batorego.

Heffernan, R. (2013). There's No Need for the '-isation'. The Prime Minister is Merely Prime Ministerial. Parliamentary Affairs, 66(3), 636-45.

Karnowski, M., \& Mistewicz, E. (2010). Anatomia władzy. Mistewicz kontra Karnowski. Warszawa: Czerwone i Czarne.

Kochan, M. (2016). Od święta demokracji do teleturnieju. Przemiany konwencji debat telewizyjnych w Polsce. In: A. Budzyńska-Daca (ed.), 20 lat polskich telewizyjnych debat przedwyborczych (pp. 15-89). Warszawa: WP UW.

Leśniczak, R. (2018). Komunikowanie polityczne w epoce postmodernizmu i postprawdy. Analiza debaty przed wyborami parlamentarnymi w Polsce w 2015 r. Eódzkie Studia Teologiczne, 27(2), 181-95.

Markowski, R., \& Stanley, B. (2016). Rozłamy socjopolityczne w Polsce. Iluzja czy rzeczywistość?. Studia socjologiczne, 4(223), 14-40.

Mazur, M., \& Konieczny, A. (2012). Po co politykom telewizyjne debaty wyborcze? Analiza zawartości polskich debat. Studia Medioznawcze, 4, 82-94.

Mazur, M. (2014), Polityka z twarza. Personalizacja parlamentarnych kampanii wyborczych $w$ Polsce $w$ latach 1993-2011. Katowice: Wyd. Uniwersytetu Śląskiego.

Matyja, R. (2018). Wyjście awaryjne. O zmianie wyobraźni politycznej. Kraków: Karakter.

Mughan, A. (2015). Parties, Conditionality and Leader Effects in Parliamentary Elections. Party Politics, 21(1), 2839.

Peszyński, W. (2013). Prezydencjalizacja zachowań elektoratu w roku niewyborczym 2012. Political Preferences, 6, 75-90.

Peszyński, W. (2014). Prezydencjalizacja zachowań elektoratu w 2013 roku na tle porównawczym z poprzednim sezonem „niewyborczym”. Political Preferences, 8, 11-28.

Peszyński, W. (2016). Prezydencjalizacja zachowań wyborczych w elekcji parlamentarnej w 2015 roku. Political Preferences, 12, 37-56.

Peszyński, W. (2016a). Presidentialization of Parliamentary Election. The Case of Polish Election of 2015. Roczniki Nauk Społecznych, 8(1), 87-106.

Peszyński, W. (2018). Prezydencki i parlamentarny style kampanii wyborczej. Roczniki Nauk Społecznych, 46(3), $143-62$.

Poguntke, T., \& Webb, P. (2005). The Presidentialization of Politics. Oxford: Oxford University Press.

Poguntke, T., \& Webb, P. (2013). The Presidentialisation of Politics Thesis Defended. Parliamentary Affairs, 66(3), 646-54.

PKW (2018). National Election Commission, Results of Voting of Local Elections 2018. Państwowa Komisja Wyborcza. https://wybory2018.pkw.gov.pl/pl/geografia\#tgeneral_committee_stat (29/06/2019)

Schulze, H. (2016). The Spitzenkandidaten in the European Parliament Election Campaign Coverage 2014 in Germany, France, and the United Kingdom. Political and Governance, 4(1), 23-36.

Stankiewicz, A. (2018). Kaczyński złapał zadyszkę. Tygodnik Powszechny, 44(3616).

Sutowski, M. (2019). Flis: Polak płakat jak glosowat. Krytyka Polityczna. https://krytykapolityczna.pl/kraj/wywiadeurowybory-flis/ (4/07/2019).

Szacki, W (2018). Co wyszło z urny. Polityka, 43.

Turska-Kawa, A. (2018). Determinanty chwiejności wyborczej na poziomie lokalnym. Athenaeum Polskie Studia Politologiczne, 58, 100-13.

Żukiewicz, P. (2013). Przywództwo prezydenckie w państwach Europy Środkowej i Wschodniej po 1989 roku. Analiza porównawcza. Toruń: Wydawnictwo Adam Marszałek. 